\title{
Kualitas Soal Penilaian Akhir Semester (PAS) Buatan Guru Mata Pelajaran Kimia Kelas X IPA SMA Negeri Di Kabupaten Seruyan Pada Semester Ganjil Tahun Ajaran 2018/2019
}

\author{
Aik Sopiah*, Suandi Sidauruk, Nopriawan Berkat Asi \\ Program Studi Pendidikan Kimia, Universitas Palangka Raya, Indonesia \\ *E-mail: aiksopiah@gmail.com
}

\begin{abstract}
Abstrak
Soal yang digunakan pada Penilaian Akhir Semester (PAS) merupakan soalsoal buatan guru. Penelitian ini bertujuan untuk mengetahui dan mendeskripsikan tingkat kualitas soal Penilaian Akhir Semester (PAS) buatan guru Mata Pelajaran Kimia Kelas X IPA SMA di Kabupaten Seruyan pada Semester Ganjil Tahun Ajaran 2018/2019.

Penelitian ini merupakan penelitian deskriptif. Objek dalam penelitian ini adalah soal buatan guru dan jawaban siswa hasil Penilaian Akhir Semester (PAS) mata pelajaran Kimia kelas X IPA SMA A, kelas X IPA SMA B, dan kelas X IPA SMA C pada semester ganjil tahun ajaran 2018/2019. Teknik pengumpulan data penelitian ini adalah metode dokumentasi. Analisis data dilakukan secara deskriptif berupa logical review dan empirical review.

Hasil penelitian menunjukkan bahwa logical review diperoleh tingkat kesesuaian soal dengan kompetensi dasar sebesar 93,3\%. Kesesuaian soal dengan aspek materi, konstruksi, dan bahasa pada X IPA rata-rata sebesar 93,29\%. Distribusi jenjang ranah kognitif taksonomi Bloom yang terukur pada tiga set soal dari tiga SMA yang berada di Kabupaten Seruyan adalah C1 sebanyak 59 (67\%) soal, C2 sebanyak 33 (29,5\%) soal, C3 sebanyak 13 (35,5\%) soal, C4 sebanyak 0\%, C5 sebanyak 0\%, dan C6 sebanyak 0\%. Analisis secara empirical review menghasilkan data reliabilitas, indeks daya beda, indeks tingkat kesukaran, dan efektifitas distraktor. Berdasarkan aspek-aspek tersebut kualitas soal PAS berdasarkan indeks daya beda, indek tingkat kesukaran dan distraktor diperoleh 79 $(60,6 \%)$ soal berkualitas baik dan $36(38,8 \%)$ soal berkualitas sangat tidak baik.
\end{abstract}

Kata Kunci : kualitas soal, reliabilitas, daya beda, tingkat kesukaran, efektivitas distraktor 
Aik Sopiah (110-126)

\section{Pendahuluan}

Pendidikan Nasional berfungsi mengembangkan kemampuan dan membentuk watak serta peradaban bangsa yang bermartabat dalam rangka mencerdaskan kehidupan bangsa, bertujuan untuk berkembangnya potensi peserta didik agar menjadi manusia yang beriman dan bertakwa kepada Tuhan Yang Maha Esa, berakhlak mulia, sehat, berilmu, cakap, kreatif, mandiri dan menjadi warga negara yang demokratis serta bertanggung jawab. Hal ini diamanatkan di dalam Undang-Undang Republik Indonesia Nomor 20 Tahun 2003 tentang Sistem Pendidikan Nasional.

Berkaitan dengan upaya peningkatan kualitas pendidikan, Sudjana (2014) mengungkapkan bahwa salah satu upaya dalam meningkatkan kualitas proses dan hasil belajar sebagai bagian dari peningkatan kualitas pendidikan dapat dilakukan melalui sistem penilaian. Dalam penilaian proses dan hasil belajar siswa disekolah, aspek-aspek yang berkenaan dengan pemilihan alat penilaian, penyusun soal, pengolahan dan interprestasi data hasil penilaian, analisis butir soal untuk memperoleh kualitas soal yang memadai, serta pemanfaatan data hasil penilaian sangat berpengaruh terhadap kualitas lulusan. Hal yang perlu dilakukan untuk mengetahui pencapaian hasil belajar tersebut adalah penilaian. Penilaian merupakan salah satu komponen penting dan tahap yang harus dipenuhi oleh guru untuk mengetahui kualitas pembelajaran (Arifin, 2012). Guru dapat mengukur apakah peserta didik sudah menguasai mata pelajaran yang telah diajarkan atau belum dengan melakukan kegiatan penilaian.

Mansyur dkk (2015) menyatakan bahwa penilaian merupakan komponen penting dalam penyelenggaraan pendidikan. Upaya meningkatkan kualitas 
pendidikan dapat ditempuh melalui peningkatan kualitas pembelajaran dan kualitas sistem penilaiannya. Keduanya saling terkait, sistem pembelajaran yang baik akan menghasilkan kualitas belajar yang baik. Kualitas pembelajaran ini dapat dilihat dari hasil penilaiannya. Selanjutnya sistem penilaian yang baik akan mendorong pendidik untuk menentukan strategi mengajar yang baik dalam memotivasi peserta didik untuk belajar yang lebih baik. Oleh karena itu, dalam upaya peningkatan kualitas pendidikan diperlukan perbaikan sistem penilaian yang diterapkan agar amanat Undang-Undang Republik Indonesia Nomor 20 Tahun 2003 tentang Sistem Pendidikan Nasional dapat terwujud.

Berkaitan dengan pernyataan tersebut, Pemerintah Repuplik Indonesia telah menetapkan Standar Penilaian Pendidikan didalam Standar Nasional Pendidikan. Peraturan Pemerintah No. 19 Tahun 2005 Pasal 63 ayat 1 menyatakan penilaian pendidikan pada jenjang pendidikan dasar dan menengah terdiri atas penilaian hasil belajar oleh pendidik; penilaian hasil belajar oleh satuan pendidikan; dan penilaian hasil belajar oleh Pemerintah. Pasal 64 ayat 1 (hasil perubahan pertama) menyatakan penilaian hasil belajar oleh pendidik dilakukan secara berkesinambungan untuk memantau proses, kemajuan belajar, dan perbaikan hasil belajar Peserta Didik.

Berdasarkan hal tersebut, selain sebagai pedidik, guru juga merupakan penilai sebagaimana yang dinyatakan oleh Widoyoko (2016) diantara tugas guru dalam kegiatan pembelajaran adalah merencanakan kegiatan pembelajaran, melaksanakan pembelajaran dan menilai hasil belajar. Kemampuan guru dalam memilih dan menyusun instrumen penilaian yang sesuai dengan tujuan penilaian, mengolah dan menafsirkan hasil penilaian akan sangat berpengaruh terhadap 
kualitas data hasil penilaian sebagai dasar pengambilan keputusan. Oleh karena itu, kemampuan menilai proses dan hasil belajar siswa merupakan salah satu kompetensi yang harus dikuasai seorang guru maupun calon guru. Guru dalam melakukan penilaian dan evaluasi hasil belajar peserta didik membutuhkan instrumen penilaian yang valid dan reliabel agar dapat mengukur dengan baik tingkat pencapaian kompetensi peserta didik. Untuk memperoleh instrumen penilaian yang valid dan reliabel maka guru harus melakukan analisis butir soal yang bertujuan untuk mengkaji dan menelaah setiap butir soal agar diperoleh soal yang bermutu sebelum soal digunakan. Soal yang bermutu jika digunakan dalam penilaian dan evaluasi hasil belajar akan memberikan informasi yang tepat sesuai dengan tujuannya misal, mampu membedakan peserta didik yang sudah atau belum kompeten. Analisis butir soal mencakup analisis kualitatif (validitas isi dan konstruk) dan analisis kuantitatif (tingkat kesukaran, daya pembeda, validitas, dan reliabilitas soal) (Direktorat Pembinaan SMA, 2010). Informasi yang diperoleh dari seperangkat tes sahih dan handal (hasil tes) bisa digunakan untuk memantau perkembangan mutu pendidikan. Hasil tes untuk tujuan ini harus baik, yaitu memiliki kesalahan pengukuran yang sekecil mungkin. Kesalahan pengukuran dapat disebabkan oleh kesalahan dalam menentukan sampel isi tes, variasi emosi seseorang, termasuk variasi emosi pemeriksa lembar jawaban jika lembar jawaban tes diperiksa secara manual, dapat juga disebabkan karena soal tes terlalu mudah atau terlalu sukar (Mansyur dkk, 2015).

Kegiatan menganalisis butir soal merupakan salah satu kewajiban bagi setiap guru, dikatakan kewajiban karena setiap guru pada akhirnya harus dapat memberikan informasi kepada lembaganya ataupun kepada siswanya itu sendiri 
tentang bagaimana dan sejauh mana penguasaan dan kemampuan yang telah dicapai siswa terhadap materi keterampilan-keterampilan yang telah diberikan. Sejalan dengan pengertian diatas maka Penilaian pendidikan sebagai proses pengumpulan dan pengolahan informasi untuk mengukur pencapaian hasil belajar peserta didik salah satu yang dilakukan untuk mengukur pencapaian hasil belajar yaitu dengan dilakukannya Penilaian Akhir Semester (PAS).

PAS merupakan kegiatan yang dilakukan untuk mengukur pencapaian kompetensi peserta didik yang dilakukan di akhir semester. PAS digunakan untuk memantau kemajuan belajar peserta didik setelah melakukan pembelajaran, agar dapat menentukan nilai hasil belajar peserta didik setelah proses pembelajaran dan melakukan perbaikan pembelajaran pada semester berikutnya. Pada cakupan UAS meliputi seluruh indikator yang mempresentasikan seluruh kompetensi dasar pada periode tersebut (Kemendikbud, 2013).

Tes yang baik haruslah terdiri dari soal-soal yang ditulis dengan baik agar dapat mengukur kemampuan dan keterampilan peserta didik sesuai yang diharapkan oleh tujuan pembelajaran. Tindakan membuat soal sebagai instrumen penilaian tidak bisa dilaksanakan secara sembarangan, untuk meningkatkan kualitas guru dalam membuat soal maka perlu pengetahuan tentang pembuatan tes. Motivasi berprestasi dan penerimaan informasi harus dimiliki oleh guru agar mengurangi kesenjangan antara harapan dan kenyataan yang terjadi di lingkungan dunia pendidikan dalam pembuatan soal.

Salah satu syarat soal yang bermutu baik adalah bahwa soal tersebut harus shahih (valid), handal (reliable), dan adil (fairnase). Shahih maksudnya bahwa setiap butir soal hanya mengukur satu dimensi/aspek saja atau dengan kata lain tes 
yang valid adalah tes dapat mengukur apa yang diukur. Handal maksudnya bahwa setiap alat ukur (tes) harus dapat memberikan hasil pengukuran (skor/nilai) yang tepat, ajeg, sedangkan adil maksudnya bahwa alat ukur yang digunakan berlaku sama setiap siswa peserta tes (tidak membedakan satu sama lainnya) agar suatu soal yang dipersiapkan setiap guru harus menghasilkan bahan ujian yang shahih dan benar.

Informasi yang diperoleh dari seperangkat tes sahih dan handal (hasil tes) bisa digunakan untuk memantau perkembangan mutu pendidikan. Hasil tes untuk tujuan ini harus baik, yaitu memiliki kesalahan pengukuran yang sekecil mungkin. Kesalahan pengukuran dapat disebabkan oleh kesalahan dalam menentukan sampel isi tes, variasi emosi seseorang, termasuk variasi emosi pemeriksa lembar jawaban jika lembar tes diperiksa secara manual, dapat juga disebabkan karena soal tes terlalu mudah atau terlalu sukar (Mansyur, 2015).

Salah satu soal yang telah dianalisis sebelumnya pada semester ganjil kelas X IPA di SMA Negeri Kabupaten Seruyan adalah sebagai berikut:

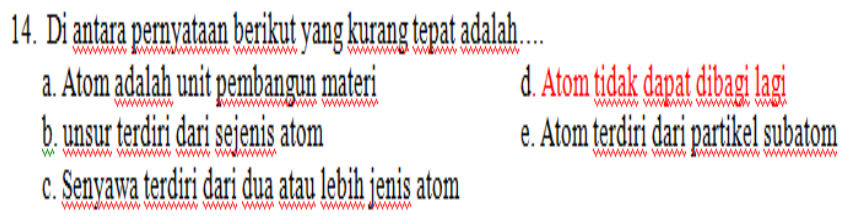

Gambar 1. Kutipan Butir Soal

Berdasarkan kaidah penulisan butir soal yang telah ditelaah dari segi konstruksi soal ini memiliki ketidaksesuaian ditinjau dari kategori pokok soal dirumuskan dengan singkat, jelas, dan tegas. Hal ini disebabkan karena siswa menjawab soal dengan asal menebak pada kunci jawaban. 
Hasil wawancara melalui media sosial terhadap guru mata pelajaran kimia di daerah menyebutkan bahwa soal yang dibuat guru yaitu soal dari buku LKS yang digunakan pada pelajaran sehari-hari, yang digunakan sebagai soal PAS. Hal ini mengakibatkan banyak soal yang sesuai karena soal tersebut dipilih oleh guru untuk dicantumkan kedalam soal PAS tersebut. Hasil wawancara terhadap beberapa guru kimia di Kabupaten Seruyan menyebutkan bahwa kebanyakan guru menggunakan soal-soal yang ada dibuku, sehingga soal evaluasi yang selama ini dilaksanakan belum pernah memperhatikan penilaian butir-butir soal. Oleh karena itu, kualitas butir soal yang diujikan tidak diketahui apakah sudah termasuk soalsoal yang memenuhi syarat sebagai alat ukur atau belum.

Guru dalam melakukan penilaian dan evaluasi hasil belajar peserta didik membutuhkan instrumen penilaian yang valid dan reliabel agar dapat mengukur dengan baik tingkat pencapaian kompetensi peserta didik. Untuk memperoleh instrumen penilaian yang valid dan reliabel maka guru harus melakukan analisis butir soal yang bertujuan untuk mengkaji dan menelaah setiap butir soal agar diperoleh soal yang bermutu sebelum soal digunakan. Soal yang bermutu jika digunakan dalam penilaian dan evaluasi hasil belajar akan memberikan informasi yang tepat sesuai dengan tujuannya misal, mampu membedakan peserta didik yang sudah atau belum kompeten. Analisis butir soal mencakup analisis kualitatif (validitas isi dan konstruksi) dan analisis kuantitatif (tingkat kesukaran, daya pembeda, validitas, dan reliabilitas soal) sebelumnya telah dilakukan oleh Chrisnadi (2017) dan Salvina (2019). 
Penelitian ini bertujuan untuk melakukan menguji dan mengetahui "Kualitas Soal Penilaian Akhir Semester (PAS) Buatan Guru Mata Pelajaran Kimia Kelas X IPA SMA di Kabupaten Seruyan pada Semester Ganjil Tahun Ajaran 2018/2019”.

\section{Metode Penelitian}

Penelitian ini tergolong penelitian deskriptif. Penelitian deskriptif ditujukan untuk mendeskripsikan yang berusaha untuk memecahkan masalah atau menjawab permasalahan yang dihadapi sekarang (Arikunto, 2003).

Melalui penelitian ini peneliti berusaha untuk memecahkan masalah sesuai dengan tujuan penelitian ini, maka peneliti mendeskripsikan kualitas soal Penilaian Akhir Semester (PAS) buatan guru mata pelajaran kimia SMA di Kabupaten Seruyan kelas X IPA pada semester ganjil tahun ajaran 2018/2019.

Penelitian ini dilaksanakan di SMA Negeri yang berada di Kabupaten Seruyan yaitu SMAN 1 Hanau, SMAN 1 Batu Ampar, dan SMAN 2 Seruyan Tengah. Waktu penelitian ini dilakukan sejak Februari 2019 yang merupakan waktu pengambilan data dan akan dilanjutkan dengan analisis data jika semua data telah terkumpul.

Objek penelitian ini adalah soal buatan guru yang berbentuk pilihan ganda dan jawaban siswa pada Penilaian Akhir Semester (PAS) mata pelajaran kimia kelas X IPA SMA di Kabupaten Seruyan pada semester ganjil tahun ajaran 2018/2019. Asumsi penelitian ini yaitu soal Penilaian Akhir Semester (PAS) mata pelajaran kimia kelas X buatan guru SMA di Kabupaten Seruyan adalah tes non standar yang disusun berdasarkan bahan dan tujuan khusus yang dirumuskan oleh para guru serta belum pernah dianalisis kualitasnya baik secara logical review 
maupun empirical review. Data hasil Penilaian Akhir Semester (PAS) adalah data yang sesungguhnya (hasil tes peserta didik di kelas dan mata pelajaran yang dikelola guru kimia di sekolah tempat penelitian).

Pengumpulan data pada penelitian ini menggunakan metode dokumentasi. Metode dokumentasi yaitu mencari data mengenai hal-hal atau variabel yang berupa catatan, transkrip, buku, surat kabar, majalah, prasasti, notulen rapat, legger, agenda, dan sebagainya (Winarno, 2013). Data yang dikumpulkan pada penelitian ini berupa data sekunder. Data sekunder merupakan sumber data penelitian yang diperoleh peneliti melalui media perantara, data sekunder umumnya berupa bukti, catatan atau laporan historis yang telah tersusun dalam arsip.

\section{Hasil Penelitian Dan Pembahasan}

Hasil Analisis Logical Review sebelum penyusunan kisi-kisi soal, hal yang harus dilakukan adalah menentukan kompetensi dasar (KD) terlebih dahulu. Pada kesesuaian dengan aspek materi sebelumnya, hal yang juga harus diperhatikan adalah kesesuaian soal dengan indikator. Namun, seluruh guru kimia di SMA tempat pelaksanaan penilaian tidak ada yang membuat kisi-kisi soal termasuk indikator soal terlebih dahulu, guru hanya langsung membuat soal sesuai dengan materi yang telah dipelajari pada semester ganjil tahun ajaran 2018/2019. Oleh karena itu, tingkat kesesuaian soal dengan kompetensi dasar juga diperlukan untuk mengukur sejauh mana pembelajaran telah terlaksana pada semester tersebut, dan apakah sudah sesuai dan mewakili isi silabus/ kurikulum yang berlaku. 
Aik Sopiah (110-126)

Jika ditinjau dari kesesuaian soal dengan kompetensi dasar bahwa 100 $(93,3 \%)$ soal merupakan soal yang sesuai dengan kompetensi dasar dan $1(6,6 \%)$ soal merupakan soal yang tidak sesuai dengan kompetensi dasar. Secara keseluruhan menunjukkan bahwa sekolah $\mathrm{B}$ dan $\mathrm{C}$ yang sesuai dengan kompetensi dasar yaitu 100\%, sedangkan sekolah A yaitu $80 \%$ karena merupakan ada kompetensi dasar yang tidak sesuai.

Kaidah penulisan butir soal salah mengatur atau memberi rambu-rambu tentang bagaimana penyusunan, salah satunya adalah soal pilihan ganda, yang meliputi aspek materi, konstruksi, dan bahasa. Analisis kesesuaian butir soal dengan aspek materi, konstruksi, dan bahasa adalah salah satu cara untuk mengetahui kesahihan/ kehandalan soal. Soal yang sahih dan handal harus dirumuskan melalui penyususnan kisi-kisi dan kaidah penulisan butir soal. Hal tersebut merupakan salah satu cara untuk mengetahui keakuratan penilaian, karena ketepatan materi yang diujikan dan keterbacaan soal adalah kunci dari keakuratan hasil penilaian.

Secara umum, tingkat kesesuaian untuk aspek materi dan konstruksi tergolong tinggi bahkan sangat tinggi sehingga masing-masing aspek yang dinilai ada yang tekategori baik dan sangat baik. Untuk aspek bahasa, ternyata tingkat kesesuaiannya sangat rendah pada tiap-tiap SMA yang mengakibatkan rata-rata kesesuaian keseluruhan soal dengan aspek bahasa juga rendah dan memiliki kategori kurang baik. Hal tersebut utamanya diakibatkan oleh penulisan butir soal yang tidak sesuai EYD. Hampir $90 \%$ penulisan butir soal dari keseluruhan soal yang dianalisis tidak sesuai dengan EYD untuk aspek bahasa. 
Ranah kognitif berhubungan erat dengan kemampuan berpikir, termasuk kemampuan menghafal, memahami, mengaplikasi, menganalisis, menyintesis, dan kemampuan mengevaluasi. Hasil analisis menunjukkan bahwa pada seluruh sekolah, tingkatan berpikir tertinggi pada soal adalah C3 (mengaplikasi). Kebanyakan soal-soal adalah soal dengan tingkatan berpikir C1 (menghafal) dan C2 (memahami).

Walaupun tingkat pemahaman siswa dan keterampilan guru yang masih terbatas, diharapkan paling tidak terdapat satu atau dua soal dengan tingkat berfikir tinggi. Pada SMA A soal-soal didominasi oleh soal-soal dengan tingkatan berpikir C2 dan C3, dengan persentase masing-masing 59 (67\%) dan 33 (29,5\%) Pada SMA B soal-soal didominasi oleh oleh soal-soal C1 dan C2, dengan persentase masing-masing 13 (35,5\%). Pada SMA C soal-soal didominasi oleh soal-soal C3, Pada SMA D soal-soal juga didominasi dengan soal-soal C2 dan C3, dengan persentase masingmasing $42,28 \%$ dan $40 \%$. Belum ditemukan soal-soal berpikir tingkat tinggi pada seluruh soal yang diteliti. Hal tersebut disebabkan soal-soal yang digunakan guru diambil dari buku cetak dan kumpulan bank soalsoal ujian. Namun, guru masih belum memperhatikan kualitas soal pilihan ganda yang diambil dari sumber tersebut. Soal penilaian akhir semester yang diberikan kepada siswa lebih cenderung hanya menguji aspek ingatan $(\mathrm{C} 1)$, pemahaman (C2), dan penerapan (C3). Banyak buku yang menyajikan materi dengan mengajak siswa aktif, sajian konsep sistematis, tetapi sering di akhiri dengan soal yang kurang melatih keterampilan berpikir siswa. Sangat penting bagi guru untuk memperhatikan juga aspek ranah kognitif yang diterapkan dalam pembuatan soal- 
soal penilaian akhir semester, karena apabila semua tingkatan ranah kognitif diterapkan secara merata dan terus menerus, maka hasil penilaian akan lebih baik.

Analisis Empirical Review, selain kesesuaian isi soal, soal yang bermutu juga harus memiliki reliabilitas yang baik. Hasil penelitian menunjukkan reliabilitas rata-rata soal-soal penilaian akhir semester kimia SMA di Kabupaten Seruyan adalah 0,641 dengan kategori cukup. Artinya tingkat kejegan hasil penilaian dapat dikatakan cukup baik.

Analisis efektifitas distraktor menunjukkan hasil SMA A memiliki 9 (36\%)soal yang memiliki distraktor belum efektif, SMA B memiliki 15 (37,5\%) soal yang memiliki distraktor belum efektif, SMA C memiliki 20(50\%) soal yang memiliki distraktor belum efektif. SMA B merupakan SMA dengan soal yang memiliki distraktor belum efektif paling banyak, sedangkan SMA D merupakan SMA dengan soal yang memiliki distraktor belum efektif paling sedikit. Efektifitas distraktor dari keseluruhan soal tergolong baik dan berfungsi. terdapat kurang dari $38,8 \%$ soal dengan distraktor yang belum efektif pada masingmasing SM A kecuali pada SMA B yang mencapai $60,6 \%$ soal dengan distraktor belum efektif.

Soal yang baik adalah soal yang tidak terlalu sukar dan tidak terlalu mudah. Soal dikatakan sukar apabila memiliki indeks tingkat kesukaran $<0,30$, soal dikatakan sedang apabila memiliki indeks tingkat kesukaran $0,30 \leq \mathrm{TK} \leq 0,70$, sedangkan soal dikatakan sukar apabila memiliki indeks tingkat kesukaran $0,70<$ TK $<1,00$. Persentase tingkat kesukaran soal PAS kimia SMA kelas XI MIA di Kabupaten Kotawaringin Barat pada semester ganjil tahun ajaran 2018/2019 
yaitu, dari 105 soal terdapat sebanyak 55 (54,33\%) soal dengan kategori mudah, $15(14,50 \%)$ soal dengan kategori sedang, dan 33(29,50\%) dengan kategori sukar. Berdasarkan data tersebut dapat disimpulkan bahwa soal PAS didominasi oleh soal-soal sukar.

Daya beda butir soal adalah kemampuan butir tes untuk mengetahui seberapa besar suatu butir tes dapat membedakan (diskriminasi) antara peserta tes yang berkemampuan tinggi dengan peserta tes yang berkemampuan rendah. Soal diterima baik apabila memiliki indeks daya beda dengan rentang $0,25 \leq \mathrm{DB} \leq$ 1,00. Soal direvisi/kurang baik apabila memiliki indeks daya beda dengan rentang $0,10 \leq \mathrm{DB}<0,25$. Sedangkan soal dibuang/jelek apabila memiliki indeks daya beda dengan rentang DB $<0,1$. Daya Beda Soal secara keseluruhan, soal yang diterima baik terdapat $53(49,66 \%)$ soal, terdapat $19(16,33 \%)$ soal yang direvisi, dan $33(10,80 \%)$ soal yang ditolak.

Tingkat kesukaran berpengaruh langsung pada daya pembeda soal. Kesukaran soal dapat menyebabkan peserta tes dengan kemampuan rendah sangat kesulitan dalam menjawab soal tersebut. Kebanyakan siswa akan memberikan jawaban yang asal-asalan dan tanpa dipikirkan. Akibat dari hal tersebut adalah, jika jawaban asal pilih yang dilakukan peserta didik dengan kemampuan rendah tersebut benar, sedangkan jawaban siswa yang berkemampuan tinggi justru salah, maka daya beda soal akan terbalik dalam membedakan kemampuan siswa. Soal yang terlalu mudah pun akan menyebabkan daya beda soal menjadi dapat dijawab oleh siswa dari kelompok bawah. Tingkat kesukaran soal juga akan mempengaruhi keefektifan pengecoh. 
Secara empirical review, soal-soal yang baik dan layak digunakan ternyata lebih banyak jumlahnya dibandingkan dengan soal-soal yang tidak baik dan tidak layak digunakan. Soal-soal dengan kualitas sangat baik adalah soal-soal yang layak digunakan dan dapat digunakan kembali sebagai alat penilaian. Hasil penelitian menunjukkan bahwa soal dengan kualitas sangat baik seluruhnya terdapat 35 soal. Soal-soal dengan kualitas baik adalah soal-soal yang layak digunakan namun perlu diperbaiki agar dapat disimpan dan digunakan kembali. Terdapat 55 soal dengan kualitas baik. Soal-soal dengan kualitas tidak baik adalah soal yang kurang layak digunakan sebagai alat penilaian, soal seperti ini sebaiknya diperbaiki kembali. Soal-soal yang sangat tidak baik adalah soal yang sama sekali tidak layak digunakan dan harus diganti, hasil analisis menunjukkan bahwa secara keseluruhan terdapat 3 soal dengan kualitas sangat tidak baik.

\section{Simpulan}

Kualitas soal (PAS) buatan guru mata pelajaran kimia kelas X IPA di beberapa SMA di Kabupaten Seruyan dapat ditinjau dari analisis kualitatif dalam analisis logical review rata-rata kesesuaian butir soal terhadap aspek materi, konstruksi, bahasa dalam bentuk soal pilihan ganda sebesar 92,29\% dengan kategori sangat baik. Kesesuaian butir soal dengan Kompetensi Dasar 93,3\% dengan kategori sangat baik, 6,6\% dengan kategori tidak baik. Distribusi jenjang ranah kognitif taksonomi bloom yang terukur pada tiga set soal dari tiga SMA adalah C1 sebanyak 59 (67\%) soal, C2 sebanyak 33 (29.5\%)soal, C3 sebanyak $13(35,5 \%)$ soal. Kualitas soal PAS buatan guru mata pelajaran kimia dapat ditinjau dari analisis kuantitatif dalam analisis empirical review memiliki 
reliabilitas sebesar 0,641. Berdasarkan indeks tingkat kesukaran, daya beda, dan efektifitas distraktor diperoleh $79(60,6 \%)$ soal berkualitas baik dan $36(38,8 \%)$ soal berkualitas jelek.

\section{Daftar Referensi}

Chrisnadi, H. 2017. Kualitas Soal Ulangan Tengah Semester (UTS) Buatan Guru Mata Pelajaran Kimia XI dan XII IPA Beberapa SMA Di Luar Kota Palangka Raya Pada Semester Ganjil Tahun Ajaran 2016/2017. Skripsi Program Studi Pendidikan Kimia, tidak diterbitkan. Palangka Raya : Universitas Palangka Raya.

Direktorat Pembinaan SMA. 2010. Petunjuk Teknis Analisis Butir Soal Di SMA. Jakarta : Kementerian Pendidikan Nasional

Daryanto, H. 2008. Evaluasi Pendidikan. Jakarta: Rineka Cipta.

Depdiknas. 2006. Peraturan Menteri Pendidikan Nasional No 22 tahun 2006 tentang standar isi. Jakarta: Kementerian Pendidikan Nasional.

Direktarat pembinaan SMA. 2010. Juknis analisis butir soal Di SMA

Gultom, R. 2015. Kualitas Soal Buatan Guru. Skripsi Program Studi Pendidikan Kimia, tidak diterbitkan. Jakarta : Universitas Nusantara.

Iskandar, M. 2008. Metodologi penelitian pendidikan dan sosial. Jakarta: Referensi.

Mardapi, D. 2012. Pengukuran penilaian dan evaluasi pendidikan. Yogyakarta: Nuha Merdika.

Marlina. 2018. Kualitas Soal Penilaian Akhir Semester (PAS) Buatan Guru Mata Pelajaran Kimia Kelas X IPA Di Kabupaten Seruyan Pada Semester 
Aik Sopiah (110-126)

Ganjil Tahun Ajaran 2017/2018. Skripsi Program Studi Pendidikan Kimia, Tidak Diterbitkan. Palangka Raya : Universitas Palangka Raya.

Salvina, N., Sidauruk, S., \& Asi, N. B. 2019. Kualitas Soal Penilaian Akhir Semester (PAS) Buatan Guru Mata Pelajaran Kimia Kelas X SMK Jurusan Teknologi Dan Rekayasa Di Kabupaten Kotawaringin Timur Pada Semester Ganjil Tahun Ajaran 2018/2019. Jurnal Ilmiah Kanderang Tingang, 10(1), 45-55.

Nurgiyantoro, B. 2011. Penilaian Pembelajaran Bahasa. Yogyakarta: BPFE

Ratnawulan, E \& Rusdiana, H.A. 2015. Evaluasi Pembelajaran, Bandung: CV Pustaka Setia.

Sudjana, N. 1990. Penilaian Hasil Proses Belajar. Bandung: PT Remaja Rosdakarya.

Suharsimi. 2013. Dasar-Dasar Evaluasi Pendidikan Edisi 2. Jakarta: Bumi Aksara.

Suharsimi. 1999. Dasar-dasar Evaluasi Pendidikan Edisi Revisi. Jakarta: Bumi Angkasa.

Sukardi. 2011. Metodologi Penelitian pendidikan kompetensi dan prakteknya. Jakarta: Bumi Aksara

Wahyuningsih, T., E. 2015. Analisis Butir Soal Tes Objektif Buatan Guru Ulangan Semester Ganjil Mata Pelajaran Ekonomi Kelas X di SMA Negeri 1 Tahun Ajaran 2013/2014. Yogyakarta. Universitas Negeri Yogyakarta.

Zainal, A. 2016. Evaluasi pembelajaran. Bandung: Remaja Rosdakarya.

Zainal, A. 2014. Evaluasi Pembelajaran. Bandung: PT Remaja Rosdakarya. 
Vol.10 No.02 Jurnal Ilmiah Kanderang Tingang

Zainal, A. 2011. Evaluasi Pembelajaran Prinsip, Teknik Analisis Validitas, Reliabilitas (Atik Fitriatun) 11 Prosedur. Bandung: PT remaja Rosdakarya. 